\title{
Initial Coin OfFering as a Funding Source for Projects
}

\author{
Agnieszka Wis \\ Wroclaw University of Economics, \\ Faculty of Economics Management and Tourism in Jelenia Góra, \\ Department of Finance and Accounting, \\ Nowowiejska 3, 58-500, Jelenia Góra, Poland \\ e-mail: agnieszka.wis@ue.wroc.pl
}

\begin{abstract}
Each company is looking for the best way to raise capital. Nowadays there are a lot of modern possibilities of fundraising, and the development of cryptocurrencies and crowdfunding has made it possible to create new ways of financing projects. This article seeks to present the Initial Coin Offering (ICO) concept, which is an alternative and modern source of funding. It is similar to the Initial Public Offering (IPO) and crowdfunding. The aim of this article is to present the advantages and disadvantages of Initial Coin Offering. This concept is often associated with risky funding sources, but every business should be able to get acquainted with this form of financing.
\end{abstract}

\section{Keywords}

Initial coin offering; Funding source; Cryptocurrency; Crowdfunding; Initial public offering.

\section{Introduction}

Nowadays the world experiences a rapid development of technology which affects many areas of economic life. The development of the Internet and globalization enables contact with investors around the world. All this influences the development of many modern forms of financing business. Blockchains as systems enabling the creation of new virtual currencies such as bitcoins and the Ethereum system enabling the easy creation of smart contracts contributed to the increase in the popularity of Initial Coin Offering. In addition, it is influenced by greater interest in crowdfunding, which, thanks to the Internet, is a more and more frequently used form of obtaining financing. Initial Public Offering, like ICO, is a way to raise capital through investor input, but in the case of ICO there are fewer legal requirements and less financial costs. This article aims to present the ICO concept and its purpose is to indicate the advantages and disadvantages of this source of funding. Research methods which were used were mainly the study of literature, the analysis of documents and the descriptive analysis.

\section{Capital in the Enterprise}

Enterprises should strive for development. That allows them to create additional values such as creating new products or seeking new markets. Companies can also develop through innovation, which will enable them a better identification of markets. In addition, enterprises, due to their flexibility, can implement creative solutions and operate in a better and more modern way. All this can be facilitated by capital, which consists not only of financial resources, but also the entrepreneur's knowledge and skills. [1]

The capital resources consist of all physical resources, for example: devices, buildings, machines, materials, raw materials, products and financial resources, which are owned by 
enterprises as well as those that can be acquired. [2] It is necessary to accumulate capital to complete the company's development program. It follows from this that the investment possibilities of an enterprise depend on the value of capital as well as its costs. That is why it is important to determine the sources of capital, which can be divided into own and foreign ones. Equity comes from retained profits and is usually used by already operating enterprises. Then, instead of paying out the profits generated to the capital owners, the companies invest in it to maintain or strengthen their position in the market. Capital owners approve this because of the opportunity to increase the value of the company and also the possibility of greater profits in the future. The source of equity may also be an additional capital acquisition from current or new owners. This way of raising capital may differ depending on the legal and organizational form of the company. [3] However, funds provided by creditors are called foreign capital. The demand for them results from limited possibilities of raising own capital. The sources of foreign capital are bank loans, loans, trade loans, leasing, factoring, debt securities, subsidies, other assistance funds.[4] In order to accomplish the financial goals properly, one should simultaneously acquire capital from own and foreign sources and determine the optimal proportions between them. The company is not always able to shape the capital structure, which can be associated with its various sources and difficulty in obtaining them. In addition, one should always pay attention to the level of financial risk. [5]

Capital structure theories assume that the level of indebtedness grows with the size of the company. Many factors contribute to the fact that the involvement of foreign capital is higher than in small enterprises. Large companies, thanks to their capabilities, can conduct more diversified activities than small enterprises, which translates into smaller chances of liquidation. For this reason, greater security affects lower bankruptcy costs and greater ability to incur liabilities. Large companies also have lower costs of issuing financial instruments, which allows them greater freedom to shape the capital structure.[6] The cost of capital is very important in its selection. It is possible to distinguish the cost of foreign capital, which is associated with paying interest on the debt incurred, it can be called the average interest rate on debt. It is more difficult to analyze the cost of equity, which is most often perceived as an alternative cost. One should analyze the rate of return for owners in the case of investments in substitution projects. [4] Cost analysis is very important especially nowadays. The development of technology has allowed for the creation of many alternative and modern forms of financing projects.

\section{$2 \quad$ Blockchain and Cryptocurrencies}

The concept of blockchain is an innovation that has a big impact on the Internet, enterprises and the economy. It is a new generation of technology that threatens older constructions. Blockchain is a form of introducing trust in the network, thanks to which it is possible to cut off many intermediaries or disrupt their actions. These are computer systems that work all the time and offer great flexibility, which allows the creation of a new generation of services and applications. Most often, blockchains are used to create independent computer programs called intelligent contracts. It all facilitates to create financial instruments, speed up payments, organize data exchange and also facilitates interaction between machines and people. [7]

Bitcoin cryptocurrency was first described by Satoshi Nakamoto in 2008. It is described as a decentralized system of electronic payments using peer-to-peer networks that allows transactions to be made with mutual trust. Bitcoin is the first completely decentralized virtual money. The network is created by users and is not coordinated by either the bank or the payment procedure. Such decentralization is the basis for security and freedom which was the cause of the phenomenon of cryptocurrencies. [8] Otherwise, bitcoin is the first virtually verified currency, which is based on generally available source code, which operates within a 
system characterized by the emission scattering, the verification of correctness and the registration of transactions used for payment and investment purposes. [9]

After the introduction of bitcoin in 2009 the tools and infrastructure to transact digital tokens of value appeared on the Internet without trusted intermediaries. There are two ways to create a new token. Firstly - a person needs to deploy and scale a new blockchain network and secondly, issue tokens on top of an existing blockchain network. However, the concept of decentralized smart contracts appeared with the introduction of next cryptocurrency Ethereum in 2015. The Ethereum blockchain provided the infrastructure for transacting digital tokens and the capability for easy creation and autonomous management of other secondary digital tokens of value without trusted intermediaries in the open public Internet. Using the concept of smart contracts tokens can be made to be more easily tradable, created and allocated to users. This process of creating tokens and distributing them to users is called an Initial Coin Offering(ICO) process, and can be seen as a novel distribution channel for assets.[10] Tokens have turned out to be a successful way for startups to raise financing. Companies have started to make Initial Coin Offerings (ICOs) instead of going to the expense of making an Initial Public Offering (IPO) or the trouble of convincing a venture capitalist to back the company.[11] The development of modern technologies has allowed not only the development of ICO, but also crowdfunding.

\section{$3 \quad$ Crowdfunding}

The term crowdfunding is a combination of crowd and funding words. It can be described as gathering funds from an online crowd. In other words, it is social funding. The funds are obtained from a large, usually networked population with unitary small shares. A person investing in a project can sometimes count on acquiring small material prizes or obtaining profits from sales, shares and shares in ventures. There are numerous ways to define crowdfunding in the literature on the subject. Another definition states that the essence of this form of raising capital is the use of the crowd to finance small enterprises, for which it is not possible to raise capital through traditional methods. For these needs, electronic crowdfunding platforms or social networks should be used. [12]

Crowdfunding and its idea is described in foreign literature by its goal, i.e. gathering funds for a project among the Internet community. It is an alternative to raising capital from small groups of experienced, professional investors. Crowdfunding is a form that goes to an unlimited group of investors, and each of them transfers money of a relatively low value. Another definition presents crowdfunding as making investments in various enterprises and projects using online social platforms outside the regulated capital exchange market. [13]

Crowdfunding, being a new mechanism of raising funds, is distinguished by certain features that allow it to be distinguished from public collections, donations or other traditional forms. The first feature of such crowdfunding is the transfer of cash. There is no possibility of support in any other form than money. The whole process of raising capital takes place using ICT solutions. The goal of the project is determined by the purpose of the funds and the effects of their spending. This form of obtaining funds does not require the consent of any state body and may be carried out for personal, business and public purposes. A wide community of addressees is characteristic of crowdfunding - the information about the project can reach a very large group of recipients. In addition, the opportunity to support the project is presented in an open manner, is directed to an unmarked addressee. The last important feature that distinguishes crowdfunding is the occurrence of a returnable benefit for providing financial support.[14] It may be a product at an early stage of production or finished after the completion of collecting funds or some other form, for example a discount on the price of a finished product or service. 
Crowdfunding is about obtaining financing from a certain crowd - it has its counterpart in a more traditional form of raising capital. Namely, the Initial Public Offering, where a company acquires funds through the issue of shares. And the person buying shares gains shares that translate into certain shareholder rights.

\section{$4 \quad$ Initial Public Offering}

Acquiring equity through the issue of shares is a form of public listing on the stock exchange. Such a possibility is reserved for joint-stock companies, but it is quite a popular form of running a company. Typically, changing the legal form for companies with an interesting business profile is not a serious obstacle. [15] The stock market is a very important way to raise equity. Companies entering their public market with their shares carry out initial public offering. Each subsequent offer from the same company is called a secondary offering and they can dilute their existing capital by issuing new shares or they do not dilute when the shares are sold to existing shareholders. [16]

To get to the stock exchange, a company has to complete many procedures. The company must obtain the appropriate permits, conduct a public broadcast and fulfill all information obligations. Everything begins with the preparation of a resolution of the general meeting of shareholders about the intention to introduce shares on the stock exchange. Then, select a brokerage house, investment advisers and prepare documents in line with the prospectus. Only after the approval of the prospectus by the Financial Supervision Authority, the company may submit relevant documents and applications to register the issued shares. Then, it carries out the public issue of shares. The board of the Stock Exchange decides whether these shares can be introduced to stock exchange and after the positive verification of the documents allows for debut on the stock exchange. [17]

The issue of shares allows to obtain a large capital from many small investors. The issuer usually does not undertake to return the received funds, and in the event of the company's liquidation, they are returned only after all other liabilities have been met. A shareholder may sell their shares on the secondary market for cash. A share is a security which states the share of a shareholder in the company's assets. This is proof of co-ownership of part of the company's capital. A joint-stock company is responsible for its liabilities with its own assets, while shareholders can lose most of their contribution. The shareholder has property and corporate rights along with the purchase of the shares. They have the right to participate in the company, in the general meeting, they can get the right to participate in the annual profit through a dividend. In addition, a shareholder has the right to purchase a specified number of shares from new issues, as well as the right to a part of the company's assets in the event of its liquidation.[18] Issuing shares on the stock exchange is preferred by those companies that already have experience and have used such a source of financing. There are many restrictions and costs associated with the issue of shares. Most often, the companies fear the need of spreading information about their company to the competition, and the burden of information obligations. In addition, companies are exposed to financial costs when they issue shares, they may lose control of the company through the sale of shares and must comply with complicated legal provisions. [19]

\section{$5 \quad$ Initial Coin Offering}

Initial Coin Offering (ICO) is a rapidly growing innovation in funding sources that uses blockchain technology and cryptocurrency. ICO makes it possible to raise funds by issuing tokens that can be re-sold on the secondary market or used in the future to receive products or services of a given company. It should be noted that tokens can be understood and used in various ways. ICO also has its formal requirements - it requires the issuer to develop such 
documents as "white paper" or "terms of sale of tokens", in which the most important information about the protocols and blockchains must be included. The documents must also contain the delivery method and the mechanisms for the valuation of tokens and data on the financed project, usually in the form of a business plan. The first ICO issue took place in 2014 in the USA and concerned the DAO fund and Ethereum cryptocurrency. The biggest problem related to ICO are legal regulations and the legality of such a source of obtaining funds. However, regardless of whether it is a legal way, ICO fills a certain gap in the access to capital in an innovative way in terms of technology, product and process. [20]

ICO is also the first issue of the cryptocurrencies created by the company. The simplified procedure for obtaining financing through ICO is as follows: [21]

- the creation of a new cryptocurrency,

- the introduction to the selected exchange of virtual currencies,

- ICO promotion,

- the sale of tokens and receiving traditional money or a more popular cryptocurrencies.

In addition to the virtual market introduction phase, the company may take advantage of ready-made solutions, e.g. platforms enabling the creation of its own cryptocurrency. This form of raising capital is new and the decision to implemented should be carefully considered and preceded by appropriate analyzes.[21] Komisja Nadzoru Finansowego (KNF) - Polish Financial Supervision Authority informs that investing in tokens (ICOs), is highly hazardous. Entities are using this form to raise funds. Famous people are more frequently engaged in promoting ICOs investment offers in order to make them more reliable. The KNF would like to make potential investors and entities interested in offering such products to pay attention to risks connected with ICOs. Potential buyers should be especially aware of the possibility of losing all invested capital and the possible lack of legal protection. The KNF announced the following risks: prone to frauds and other irregularities, high risk of loss of some of the invested funds, inadequate documentation and flaws of the used technology. [22]

ICOs are usually carried out by companies or organizations that want to implement projects related to modern technology. Unlike IPO, they are carried out without the supervision of market regulators and the issuer does not have to meet many formal requirements. The ICO process usually takes a short time and is available globally to all concerned. The buyer can count on an increase in the value of tokens when the financed project is successful in the market. Funds collected in such a way can be allocated to the development of an already operating project as well as in the phase of the concept itself. All these features of ICO make them very risky investments, but at the same time with a potentially very high rate of return. The risk results from the fact that the financed project may fail. In addition, there is not enough information about the company that carries out tokens. Some ICO offers are frauds issuers do not plan to implement any projects other than collecting funds. Among the completed projects, which brought profits of several hundred thousand percent, there is Ethereum mentioned, for the preparation of 16 million dollars, as well as cryptocurrencies IOTA, NEO. [23]

Just like in crowdfunding, with which ICO has many common features, the first tokens buyers can be rewarded with discounts or bonuses in the form of additional funds allocations as well as other incentives. The token price can be fixed in the whole collection process, but there are also ICOs using other mechanisms, usually a division into tranches. The IPO can be associated with the method of distribution of a token pool - often a predetermined part goes to the originators of campaigns and other "insiders". [24] 
Earlier analyzes of other sources of financing projects show many differences and similarities of ICO to IPO or crowdfunding. Each of these forms is aimed at raising capital in relatively small amounts, but from a large number of people, which allows to obtain a large amount of financial resources. Each form has its advantages and disadvantages. In the case of Initial Coin Offering, the following advantages can be distinguished:

- using a blockchain system that allows cutting off many intermediaries,

- these systems offer great flexibility and work all the time,

- there is no limit to the organizational form of the activity as in the case of IPO,

- fewer procedures and requirements compared to IPO,

- access to capital in a technological, product and process innovative way,

- allows to create a new cryptocurrency,

- there are platforms that facilitate the creation of cryptocurrency,

- the ICO process is short,

- anyone interested in the global nature of ICO can participate in the purchase of tokens,

- funds collected in this way may be allocated for the development of a working project and also in the concept phase.

The disadvantages are primarily connected with the risk for the investor and the following can be mentioned:

- formal requirements in the form of developing a white paper and the conditions of the sale of tokens,

- the lack of or little legal regulations,

- financial supervision authority warnings about high danger of investment in ICO,

- many ICOs are carried out in order to raise funds without carrying out the project,

- there is no legal protection for companies or investors,

- many ICO are scams,

- defects of used technology - the possibility of hacker attacks,

- a project financed in this way may fail,

- tokens can be distributed among project originators or other important persons.

\section{Conclusion}

Today, many financing sources can be selected for financing projects. It is necessary to analyze what capital will be more suitable for the company, whether its own or foreign. At the same time, the proportion between these capitals is important. For this reason, it is important to know the different forms of obtaining funds in order to be able to choose the right one. Initial Coin Offering is a relatively new form that does not yet have adequate legal regulations, which creates many threats both for companies and investors. However, thanks to this it is a more accessible way for more companies. This is due to less tight requirements and the possibility of using easily accessible internet. ICO is undoubtedly an interesting alternative for IPO and crowdfunding. The opportunities for further development of this form may be the creation of certain global regulations, which could increase investor confidence. Such a solution would be extremely difficult due to the general availability of conducting ICO. This article has achieved the goal by presenting the advantages and disadvantages of this form of project financing. The most important disadvantages relate primarily to the fact that it is a very new and little controlled source of financing. However, it is a modern form that arouses great interest. Many companies and investors are very interested in ICO and it would probably be more interesting if the disadvantages of this source of financing projects were limited. 


\section{Literature}

[1] PAKULSKA, T.: Przedsiębiorstwo. Wyzwania. Niepewność. Oficyna Wydawnicza SGH, Warszawa, 2017. ISBN 978-83-8030-191-7.

[2] MAREK, S.: Podstawy ekonomiki przedsiębiorstw. Walkowska Wydawnictwo, Szczecin, 1998.

[3] SIERPIŃSKA, M.; JACHNA, T.: Ocena przedsiębiorstwa wedtug standardów światowych. Wydawnictwo Naukowe PWN, Warszawa, 1999. ISBN 978-83-01-149871.

[4] NEHREBECKA，N.; BIAŁEK-JAWORSKA，A.; DZIK-WALCZAK， A.: Źródta finansowania przedsiębiorstw. Stan badań i ich metaanaliza. Difin, Warszawa, 2016. ISBN 978-83-8085-094-1.

[5] KACZMARZYK, J.: Uwarunkowania Finansowe działalności przedsiębiorstw na jednolitym rynku europejskim. Studia Ekonomiczne Zeszyty Naukowe Uniwersytetu Ekonomicznego w Katowicach. 2016, Vol. 282, pp. 46-56. ISSN 2083-8611.

[6] ŁUKASIK, G.; NACZYŃSKI, D.: Relacje kapitałowe przedsiębiorstw w Polsce i wybranych krajach europejskich. Studia Ekonomiczne Zeszyty Naukowe Uniwersytetu Ekonomicznego w Katowicach. 2016, Vol. 282, pp. 80-93. ISSN 2083-8622.

[7] SZPRINGER, W.: Blockchain jako innowacja systemowa. Wydawnictwo Poltext, Warszawa, 2019. ISBN 978-83-7561-961-4.

[8] BALA, S.; KOPYŚCIAŃSKI, T.; SROKOSZ, W.: Kryptowaluty jako elektroniczne instrumenty ptatnicze bez emitetnta. Wydawnictwo Uniwersytetu Wrocławskiego, Wrocław, 2016. ISBN 978-83-229-3541-5.

[9] PIOTROWSKA, A. I.: Bitcoin. Ptatnicze i inwestycyjne zastosowania kryptowaluty, CeDeWu, Warszawa, 2018. ISBN 978-83-8102-025-1.

[10] SEHRA, A.; SMITH, P.; GOMES, P.: Economics of Initial Coin Offerings. [online]. 2017. [accessed 2019-04-15]. Available from WW: http://www.allenovery.com/SiteCollectionDocuments/ICO-Article-Nivaura-201708220951\%20\%20-\%20Final\%20Draft.pdf

[11] CONLEY, J.: Blockchain and the Economics of Crypto-tokens and Initial Coin Offerings. [online]. 2017. [accessed 2019-04-15]. Available from WWW: http://www.accessecon.com/Pubs/VUECON/VUECON-17-00008.pdf

[12] DZIUBA, D. T.: Rozwój systemów crowdfundingu w globalnej gospodarce elektronicznej. Zeszyty Naukowe Uniwersytetu Szczecińskiego. Studia Informatica. 2014, Vol. 798, Issue 34, pp. 19-32. ISSN 0867-1753. Available from WWW: http://yadda.icm.edu.pl/yadda/element/bwmeta1.element.ekon-element-000171363267

[13] KORDELA, D.: Crowdfunding w Polsce - koncepcja finansowania społecznościowego / Crowdfunding in Poland - the concept of social financing. Prace Naukowe Uniwersytetu Ekonomicznego we Wrocławiu. DOI: 10.15611/pn.2016.436.15

[14] KOZIOŁ-NADOLNA, K.: Crowdfunding jako źródło finansowania innowacyjnych projektów. Zeszyty naukowe Uniwersytetu Szczecińskiego, Finanse, Rynki Finansowe, Ubezpieczenia. 2015, Vol. 854, Issue 73 pp. 671-683. ISSN 1640-6818.

[15] GRZYWACZ, J.: Źródła finansowania działalności rozwojowej przedsiębiorstw $w$ Polsce. Oficyna wydawnicza szkoła główna handlowa w Warszawie, Warszawa, 2016. ISBN 978-83-8030-067-5. 
[16] PŁÓKARZ, R.: Globalne rynki finansowe. Praktyka funkcjonowania. Wydawnictwo Naukowe PWN, Warszawa, 2013. ISBN 978-83-011-6064-7.

[17] DOBOSIEWICZ, Z.: Giełda, zasady działania, inwestorzy, rynki giełdowe. PWE, Warszawa, 2013. ISBN 978-83-208-2056-0.

[18] BEDNARZ, J.; GOSTOMSKI, E.: Źródta i sposoby finansowania przedsiębiorstw. Wydawnictwo Uniwersytetu Gdańskiego, Gdańsk, 2018. ISBN 978-83-7865-662-3.

[19] WASILEWSKA, H.; JANOWSKA, A.: Emisja akcji w drodze oferty publicznej na przykładzie spółek giełdowych. Bank i kredyt listopad-grudzień. 2005, Vol. 11, pp. 3642. ISSN 0137-5520.

[20] MOTYLSKA-KUŹMA, A.: Quo Vadis? - innowacyjne i alternatywne źródła finansowania. Finanse, Rynki Finansowe, Ubezpieczenia. DOI: 10.18276/frfu.2018.92$\underline{12}$

[21] WIŚNIEWSKA, A.: Obszary wykorzystania walut wirtualnych w działalności przedsiębiorstwa. Acta universitatis Nicolai Copernici. DOI: $10.12775 / A U N C \_$ZARZ.2018.028

[22] KNF: Komunikat KNF w sprawie sprzedaży tzw. monet lub tokenów (ang. Initial Token Offerings - ITOs lub Initial Coin Offerings - ICOs). [online]. 2017. [accessed 2019-0418]. Available from https://www.knf.gov.pl/o_nas/komunikaty?articleId=60178\&p_id=18

[23] ŻUWAŁA, A.: Możliwości wykorzystania technologii blockchain. [online]. 2018. [accessed 2019-04-18]. Available from http://www.pszw.edu.pl/images/publikacje/t087_pszw_2018_zuwala__mozliwosci_wykorzystania_technologii_blockchain.pdf

[24] KISIEL, M.: ICO - poczatki rewolucji na rynku kapitałowym? [online]. 2017. [accessed 2019-04-18]. Available from WWW: https://www.bankier.pl/wiadomosc/ICO-poczatkirewolucji-na-rynku-kapitalowym-7539606.html 


\section{INITIAL COIN OFFERING JAKO ALTERNATIVNÍ ZDROJ FINANCOVÁNÍ}

Každý podnik hledá nejlepší způsob, jak získat kapitál. Dnešní doba přináší spoustu moderních možností, a rozvoj kryptoměn a crowdfundingu umožnil vznik nových způsobů financování podnikání. Tento článek je snahou prezentovat koncepci Initial Coin Offering (ICO), která je alternativním zdrojem financování. Je podobná Initial Public Offeringu (IPO) a crowdfundingu. Cílem tohoto prŕspěvku je představit výhody a nedostatky ICO. Tato koncepce je často popisována jako rizikový zdroj financování, ale každý podnik by měl mít možnost se s touto formou financování seznámit.

\section{INITIAL COIN OFFERING ALS EINE ALTERNATIVE QUELLE DER FINANZIERUNG}

Jedes Unternehmen sucht nach einer optimalen Form des Kapitalerwerbs. Heutzutage gibt es dazu viele moderne Wege. Die Entwicklung von Kryptowährungen und Crowdfunding ermöglichten die Entstehung neuer Wege zur Finanzierung der Wirtschaftstätigkeit. Der vorliegende Beitrag stellt einen Versuch dar, die Konzeption des Initial Coin Offering (ICO) zu präsentieren, die eine alternative Quelle der Finanzierung stellen kann. Diese Finanzierungserwerbsform hat eine ähnliche Struktur wie das Initial Public Offering (IPO) oder das Crowdfunding. In dem vorliegenden Beitrag werden die Vor- und Nachteile des ICO dargestellt. Diese Konzeption wird zwar oft als eine ziemlich risikoreiche Finanzierungsquelle beschrieben; nichtsdestoweniger sollte jedes Unternehmen die Möglichkeit bekommen, sich mit dieser Finanzierungsform vertraut zu machen.

\section{INITIAL COIN OFFERING JAKO ALTERNATYWNE ŹRÓDŁO FINANSOWANIA}

Każde przedsiębiorstwo szuka najlepszej formy pozyskania kapitału. Dzisiejsze czasy dają wiele nowoczesnych możliwości, rozwój kryptowalut i crowdfundingu umożliwił powstanie nowych sposobów finansowania działalności. Niniejszy artykuł jest próbą zaprezentowania koncepcji Initial Coin Offering (ICO), która jest alternatywnym źródłem pozyskania finansowania. Jest ona zbliżona do Initial Public Offering (IPO) oraz do crowdfundingu. Niniejszy artykuł ma na celu przedstawienie zalet oraz wad ICO. Koncepcja ta jest często opisywana jako ryzykowne źródło finansowania, jednak każde przedsiębiorstwo powinno mieć możliwość zapoznania się z tą formą pozyskania kapitału. 